\title{
Spatial variation in the abundance and condition of the bivalve Nuttallia olivacea in relation to environmental factors and sublethal predation
}

\author{
Takeshi Tomiyama ${ }^{1,2, *}$, Nobuhiro Komizunai ${ }^{1}{ }$, Kinuko Ito $^{1}$, Michio Omori $^{1}$ \\ ${ }^{1}$ Graduate School of Agricultural Science, Tohoku University, Sendai 981-8555, Japan \\ ${ }^{2}$ Present address: Soma Branch, Fukushima Prefectural Fisheries Experimental Station, Soma 976-0022, Japan
}

\begin{abstract}
Our aim was to assess the spatial heterogeneity in the abundance and condition of the tellinacean bivalve Nuttallia olivacea in estuarine tidal flats, as well as to reveal the relationships between these variables and abiotic and biotic factors. The intensity of sublethal siphon predation by juvenile stone flounder Platichthys bicoloratus was considered as a possible factor affecting the bivalve condition. A 2-scale sampling of stations at 200 to $800 \mathrm{~m}$ intervals and 2 to 5 plots at 5 to $20 \mathrm{~m}$ intervals on a transect line at each station was conducted in the Natori River estuary, Japan. Abundance and somatic condition greatly varied at both scales. Densities varied from 0 to 4902 ind. $\mathrm{m}^{-2}$ among stations and from 2480 to 6448 ind. $\mathrm{m}^{-2}$ among plots at the station with the highest density. Body mass index varied from 4.0 to 5.0 between stations and from 4.9 to 5.7 between plots at the station with the highest body mass. It was commonly observed that $N$. olivacea was abundant and that body condition was high at sites with low silt-clay contents and low elevations, as revealed by generalized linear models. A negative influence of siphon predation was detected only on somatic condition, but it accounted for only $1.2 \%$ of the variation, whereas environmental variables accounted for $30.2 \%$. These results indicate that environmental variables are key factors affecting bivalve abundance and condition, while sublethal predation is only a potential factor affecting bivalve condition.
\end{abstract}

KEY WORDS: Bivalve - Spatial scales - Generalized linear models · Body condition - Flatfish · Intertidal flat Resale or republication not permitted without written consent of the publisher

\section{INTRODUCTION}

Bivalves generally are dominant members of the macrobenthos community and play important roles as secondary producers in estuaries. The abundances and assemblage structures of bivalves and other macrobenthos vary spatially at various scales from 10 to $10^{5} \mathrm{~m}$ (Morrisey et al. 1992, Ysebaert \& Herman 2002, Thrush et al. 2005). The spatial distribution patterns are closely related to environmental factors, such as sediment types, tidal level, and salinity (Ysebaert \& Herman 2002, Nanami et al. 2005, Kanaya \& Kikuchi 2008).
Environmental factors also affect the physiological processes of organisms. For example, the growth and somatic condition of bivalves are higher in lower intertidal areas due to longer feeding time (Honkoop \& Beukema 1997, reviewed by Cardoso et al. 2007). However, multiple environmental factors interact to influence bivalves. Systematic surveys of various environments are effective for understanding the physiological responses of bivalves to complex environmental pressures in estuaries in which sediment, tidal level, and other factors vary spatially. Azouzi et al. (2002) conducted a survey covering an entire bay and revealed that the variations in density and body mass 
of the tellinid bivalve Macoma balthica were chiefly related to the sediment type and tidal level, respectively. Such a systematic study is rarely found in the literature.

Biotic factors, not only abiotic factors, may influence bivalves. Exposure to predators increases the burying depth of bivalves (Edelaar et al. 2005). Deep burying of bivalves to prevent predation by birds may reduce bivalve condition (de Goeij \& Luttikhuizen 1998). Sublethal tissue predation caused by flatfishes and crabs (de Vlas 1979, Salas et al. 2001) has negative impacts on bivalves, including growth inhibition (Peterson \& Quammen 1982, Coen \& Heck 1991, Irlandi \& Mehlich 1996) and deterioration in somatic condition (Hodgson 1982, Bonsdorff et al. 1995). Other possible factors, such as diseases and parasite loads, may reduce bivalve growth and/or condition.

We focused on the condition of bivalves as an indicator of their physiological responses to different environments. We used the tellinacean suspension-feeding bivalve Nuttallia olivacea as a model organism. The growth and somatic condition of $N$. olivacea is higher in sandy areas than in muddy-sand areas in the estuary (Ito et al. 2005, Tomiyama et al. 2005). The siphons of this species are frequently cropped by juvenile stone flounder Platichthys bicoloratus (Tomiyama et al. 2005, 2007, Tomiyama \& Omori 2008). Negative impacts of siphon predation on the bivalve condition have not been confirmed, although growth inhibition of the bivalves by artificial siphon removal has been observed (Tomiyama \& Omori 2007).

The present study aimed (1) to detect spatial variation in the abundance and condition of Nuttallia olivacea in the estuary, (2) to detect environmental factors affecting spatial variation, (3) to test whether negative effects of sublethal siphon predation by stone flounder are detectable on the somatic condition of $N$. olivacea, and (4) to determine the relative importance of sublethal predation and environmental factors for the variation in bivalve condition. We investigated the variation in bivalve abundance and condition at different spatial scales (200-800 $\mathrm{m}$ and at 5-20 m intervals); assemblage patterns of macrobenthos varied on both scales (Tomiyama et al. 2008). In addition to the field survey, we conducted a laboratory experiment in which $N$. olivacea were reared with stone flounder in order to confirm the negative influences of sublethal predation on bivalve condition.

\section{MATERIALS AND METHODS}

Study site. The study site was the Natori River estuary in Sendai Bay in Japan. The river is about $200 \mathrm{~m}$ wide. The Hiroura Lagoon (about $1500 \mathrm{~m}$ long) is near the mouth of the river. Tidal range is $<1.5 \mathrm{~m}$. To conduct a 2-scale sampling, 11 intertidal stations at 200 to $800 \mathrm{~m}$ intervals, each with 2 to 5 plots at 5 to $20 \mathrm{~m}$ intervals across the shoreline, were established (Fig. 1). These stations cover most intertidal areas in the estuary. Plots were assigned designations from ' $a$ ' to ' $e$ ', with Plot a being located nearest to the subtidal zone (see Tomiyama et al. 2008).

Silt-clay contents, salinity, relative elevation, and chlorophyll a ( $\mathrm{chl}$ a) levels were chosen as environmental factors. Relative elevation $(\mathrm{cm})$ of the bottom and salinity were recorded at high tides. Chl a level was regarded to indicate the relative food availability, because diatoms are the main food source of Nuttallia olivacea (Ito et al. 2005). Two sediment samples were

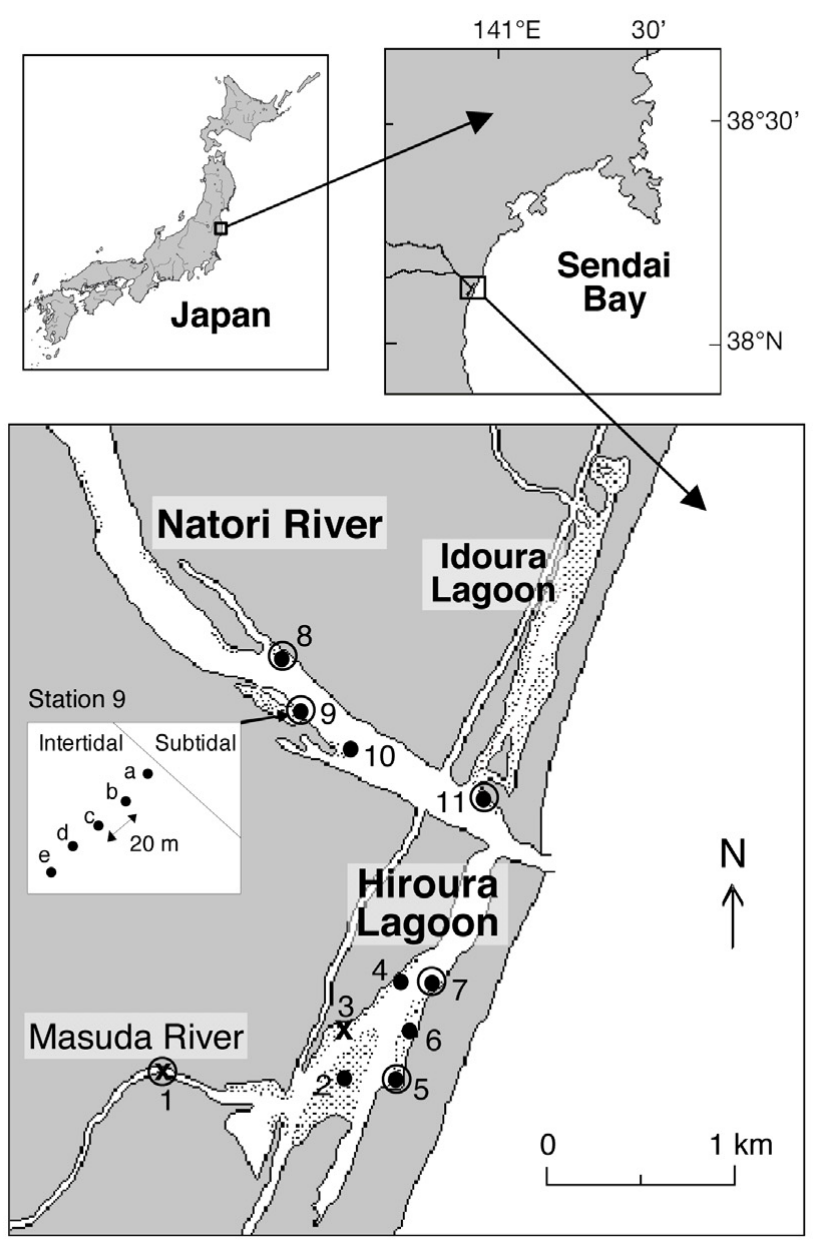

Fig. 1. Map of the study site and locations of the stations for bivalve collection. Dotted area: tidal flats. Station numbers are the same as those used in a previous study (Tomiyama et al. 2008); Stn 12 from the previous study was excluded because of complete absence of macrobenthic animals at that station. Each station had 2 to 5 plots for bivalve collection, as shown for Stn 9. Solid circles and crosses: stations with and without, Nuttallia olivacea, respectively. Open circle: locations of stone flounder collection 
collected from the surface (0 to $1 \mathrm{~cm}$ layer) of each plot for silt-clay and chl a analyses using a core sampler with a $5 \mathrm{~cm}$ diameter on the days of bivalve collection. To determine the silt-clay contents, sediment samples were dried at $80^{\circ} \mathrm{C}$ for $48 \mathrm{~h}$ (after removing organic materials with $30 \%$ hydrogen peroxide) and were then sieved through a $0.063 \mathrm{~mm}$ mesh. To assess chl a levels, the sediment samples were transferred to an acetone solution and measured using an absorption spectrophotometer. The chl a level was expressed as an amount per gram of sediment $\left(\mu \mathrm{g} \mathrm{g}^{-1}\right)$. There were no significant relationships between the 4 factors $(\mathrm{p}>0.05)$.

Six bivalve species (Nuttallia olivacea, Macoma contabulata, Laternula marilina, Ruditapes philippinarum, Corbicula japonica, and Musculista senhousia) have been observed at the study site (Tomiyama et al. 2008). $N$. olivacea are the dominant bivalve species in this estuary, although they were not found at Stns 1 and 3 (Table 1).

Stone flounder have been observed from February to June at the study site (Tomiyama \& Omori 2008). They utilize estuaries chiefly during their juvenile stage and feed largely on bivalve siphons and palps of polychaetes (Tomiyama et al. 2005, 2007). Other siphon predators have not been recognized.

Sample collection. The bivalve collection was conducted at a spring low tide during the daytime on 22 and 23 May 1997. The sampling was conducted within $2 \mathrm{~d}$ to ensure the temporal change in soft body weight was negligible. Surveys in May would be appropriate to detect the impact of sublethal predation, because siphon cropping on Nuttallia olivacea by juvenile stone flounder Platichthys bicoloratus is relatively intense from April to May (Sasaki et al. 2002, Tomiyama et al. 2004). Additionally, the survey around the spawning season of $N$. olivacea, September to October at the study site (Galimberti 1996), was avoided to minimize the effect of gonad development/expense on the soft body weight of this species. Bivalves were dug out of the sediment in a $25 \times$ $25 \mathrm{~cm}$ area to a depth of $25 \mathrm{~cm}$ in each quadrat using a spade and a $1 \mathrm{~mm}$ mesh sieve. All bivalve species were fixed with $10 \%$ formalin immediately after collection.

To determine predation intensity on siphons of Nuttallia olivacea, the density and stomach contents of stone flounder were investigated. Predation by other animals was regarded as negligible (Tomiyama et al. 2005). We collected juvenile stone flounder weekly by several push-nettings of a $0.6 \mathrm{~m}$ wide push net over $10 \mathrm{~m}$ at depths of $<0.7 \mathrm{~m}$ at Stns 1, 5, 7, 8, 9, and 11 from April to May. The density was calculated without considering the catch efficiency. Fish were preserved in $95 \%$ ethanol immediately after collection.

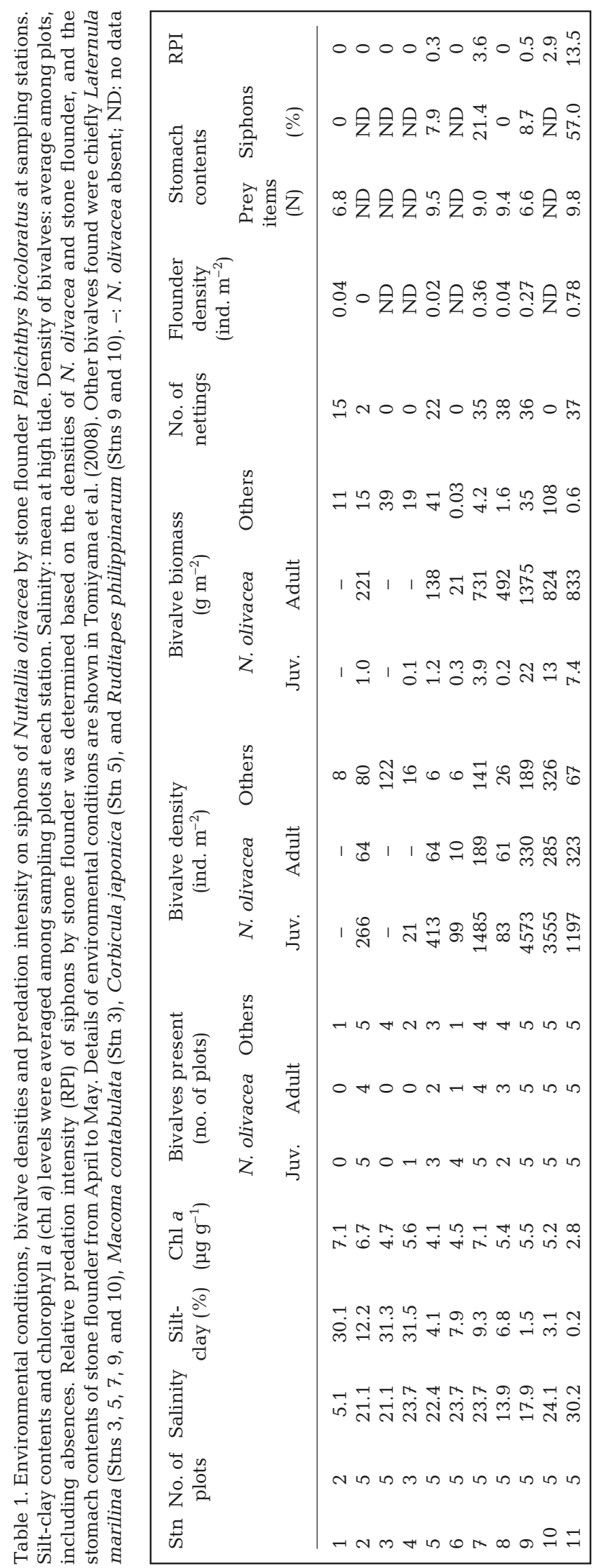


To determine bivalve biomass at each sampling plot, we measured body weight $(g)$ of all bivalve species. For Nuttallia olivacea, shell length (ShL, mm), soft body weight (SBW, g), shell weight (ShW, g), and inhalant siphon weight (ISW, g) were also measured. We defined 'juveniles' as individuals with $\leq 10 \mathrm{~mm}$ ShL and 'adults' as individuals with $>10 \mathrm{~mm}$ ShL for $N$. olivacea, although the category adults includes preadults that may not mature until the spawning season. Juveniles were seldom measured for SBW and ISW because of their small sizes. Dry weights were not determined, because the measurement errors for wet weight are likely to be small for samples fixed with formalin since excess water is blotted off with a paper towel before measurement. Individuals with extremely small siphons (4 out of 365 ind.) were excluded from the analyses.

Laboratory experiment. Nuttallia olivacea of various sizes (14 to $44 \mathrm{~mm}$ ShL) were collected at Stn 11 on 17 June 1999. They were reared in the laboratory and fed the diatoms Cylindrotheca closterium $\left(10^{6}\right.$ cells $\mathrm{ml}^{-1}$, approximately $1 \mu \mathrm{g} \mathrm{ml}^{-1}$ in chl a) twice per day for $2 \mathrm{wk}$ to allow recovery of their siphons. Approximately 25 bivalves were then randomly placed in each of 3 aquaria of $34 \times 23 \times 26 \mathrm{~cm}$ (length $\times$ width $\times$ height) with a $20 \mathrm{~cm}$ layer of sand covered by $10 \mathrm{~cm}$ of aerated brackish water (salinity $=20$ ). Individuals that failed to bury themselves were exchanged with others. After $3 d, 5$ stone flounders (38 to $62 \mathrm{~mm}$ total length) were added to an aquarium and 7 gobies Acanthogobius lactipes (43 to $55 \mathrm{~mm}$ total length) were added to another aquarium, as 2 treatments. We added the gobies to test whether bivalve condition may deteriorate by the reduction of feeding activity due to disturbance (indirect impact) instead of by siphon predation (direct impact): the goby seldom crops siphons but may disturb the bottom surface and thus inhibit bivalve feeding. As a control, the other aquarium contained bivalves only. Thus, the treatments were designated as control, flounder, and goby. We fed diatoms to bivalves twice per day and fed frozen krill to fishes once per day. Water temperature was not controlled and ranged from 21 to $25^{\circ} \mathrm{C}$ during the experiment. Brackish water was exchanged weekly.

All bivalves were dissected after $1 \mathrm{mo}$ and were measured (ShL). SBW and ISW (mg dry weight in this case) were determined: inhalant siphons and other soft tissues were dried at $80^{\circ} \mathrm{C}$ for $48 \mathrm{~h}$ and weighed using a precision electric balance (MC-5, Sartorius Inc.).

Data analyses. To investigate the spatial heterogeneity in the condition of Nuttallia olivacea, we first compared bivalve conditions between stations and between plots. We used indices for bivalve condition to minimize the size effect. The body mass index (BMI, same as condition factor), shell mass index (ShMI), and siphon condition index (SCI) were determined as follows: $\mathrm{BMI}=\mathrm{SBW} \times \mathrm{ShL}^{-3} \times 10^{5}, \mathrm{ShMI}=\mathrm{ShW} \times \mathrm{ShL}^{-3} \times$ $10^{5}$, and SCI $=\mathrm{ISW} \times \mathrm{SBW}^{-0.83} \times 10^{2}$ (Table 2). The power of ShL for SBW and ShW was assumed to be 3 because coefficients estimated by linear mixed models (response variable $=\ln$ SBW or ln ShW, explanatory variable $=\ln \mathrm{ShL}$, random effect $=$ plot) were close to 3 (2.92 and 3.08, respectively). The power of SBW for ISW was estimated to be 0.83 , although a value of 0.5 is usually used (de Vlas 1985, Tallqvist et al. 1999). BMI, ShMI, and SCI were compared between stations and between plots, using the Steel-Dwass test, a procedure for nonparametric multiple comparisons.

The intensity of predation on the siphons of Nuttallia olivacea at each station was determined as follows: stomach contents of stone flounder were sorted into siphons of $N$. olivacea and other prey, which were then counted. We used an index of relative predation intensity (RPI): $R P I=D_{F} \times N \times P_{s} \times D_{B}{ }^{-1} \times 10^{3}$, where $D_{F}$ is the density of stone flounder (ind. $\mathrm{m}^{-2}$ ), $\mathrm{N}$ is the average number of food contents per individual flounder, $\mathrm{P}_{\mathrm{S}}$ is the proportion of $N$. olivacea siphons in the total stomach contents of the flounder by number, and $\mathrm{D}_{\mathrm{B}}$ is the density of adult $N$. olivacea (ind. $\mathrm{m}^{-2}$ ). For calculation of RPI at Stn $10, \mathrm{D}_{\mathrm{F}}, \mathrm{N}$, and $\mathrm{P}_{\mathrm{S}}$ were interpolated from those at Stns 9 and 11. RPI at Stns 2, 3, 4, and 6 were assumed to be zero, because of extremely low abundances of juvenile stone flounder and/or adult $N$. olivacea.

To assess abundance-environment and conditionenvironment relationships for Nuttallia olivacea, generalized linear models (GLM) were fitted to the data. GLM was used to detect significant factors affecting the spatial distribution and condition of $N$. olivacea. For the field-survey data, we conducted 3 model fittings with stepwise backward selections based on the Akaike information criterion (Crawly 2005).

First, a GLM was developed for the presence/ absence of Nuttallia olivacea with the environmental factors. The data were fitted with a GLM with a binomial error structure and logit-link function.

Table 2. List of variables used to give bivalve conditions, and formulae for their determination

\begin{tabular}{|lcl|}
\hline Variable & Abbreviation & Formula \\
\hline Shell length $(\mathrm{mm})$ & ShL & \\
Shell weight $(\mathrm{g})$ & ShW & \\
Soft body weight $(\mathrm{g})$ & SBW & \\
Inhalant siphon weight $(\mathrm{g})$ & ISW & \\
Body mass index & BMI & $\mathrm{SBW} \times \mathrm{ShL}^{-3} \times 10^{5}$ \\
Shell mass index & ShMI & $\mathrm{ShW} \times \mathrm{ShL}^{-3} \times 10^{5}$ \\
Siphon condition index & SCI & $\mathrm{ISW} \times \mathrm{SBW}^{-0.83} \times 10^{2}$ \\
\hline
\end{tabular}


Second, a GLM was developed for the abundance of juvenile and adult Nuttallia olivacea with environmental variables. The number of collected individuals, except 0 , at each plot was used as the response variable. The number of collected $N$. olivacea for the other group (juvenile/adult) and the total number of 5 other bivalve species collected at each plot were added to the environmental factors as initial explanatory variables. The abundance data were fitted with the GLM with a negative binomial error structure and log-link function because over-dispersion was observed when the abundance data were fitted with a GLM with Poisson error structure.

Third, a GLM was developed for the weight parameters of Nuttallia olivacea in relation to abiotic and biotic variables. To consider the effects of competition for food and space, we used biomass (total weight of all bivalve species per plot) as an initial explanatory variable. Predation intensity on siphons was also added as an initial parameter for the models, except for ShW, because bivalve shells are formed cumulatively and shell mass is primarily under the long-term influence of environments (Azouzi et al. 2002). ShL after a natural logarithm transformation, $\ln \left(\mathrm{ShL}^{3}\right)$, was added as the offset term for SBW and ShW to correspond with BMI and ShMI, respectively. Similarly, the offset term $\ln \left(\mathrm{SBW}^{0.83}\right)$ was added for ISW to correspond with SCI. ShL was added to the models again as an initial explanatory variable to consider the variation among individuals, following Hattori et al. (2009). All response variables were fitted with a GLM with a Gaussian error structure and log-link function.

For the data from the laboratory experiment, GLMs were used similarly for SBW and ISW. Explanatory variables were the categorical data 'treatment' and individual ShL. The offset terms $\ln \left(\mathrm{ShL}^{3}\right)$ and $\ln \left(\mathrm{SBW}^{0.71}\right)$ were added to the models for SBW and ISW, respectively; coefficients of $\ln$ ShL and ln SBW in the linear mixed models (random effect $=$ aquarium) for ln SBW and for ln ISW were 3.02 and 0.71 , respectively.

All statistical procedures were conducted using R 2.7.0 (www.r-project.org).

\section{RESULTS}

\section{Abundance and somatic condition}

Juveniles and adults of Nuttallia olivacea were present at 35 plots (9 stations) and 29 plots (8 stations) from 50 sampling plots, respectively (Table 1). Juveniles dominated in number, while bivalve biomass mostly consisted of adults. Densities in both the number and weight of $N$. olivacea were high (>1000 ind. $\mathrm{m}^{-2}$ and $>700 \mathrm{~g} \mathrm{~m}^{-2}$ ) at Stns 7, 9, 10, and 11. Densities varied from 0 (Stns 1 and 2) to 4902 ind. $\mathrm{m}^{-2}$ (Stn 9) between stations and varied from 2480 to 6448 ind. $\mathrm{m}^{-2}$ between plots at Stn 9. The highest densities of juveniles (6128 ind. $\mathrm{m}^{-2}$ ) and adults (720 ind. $\mathrm{m}^{-2}$ ) were observed in Plots $9 \mathrm{c}$ and 9a, respectively. The highest biomass level of bivalves $\left(4837 \mathrm{~g} \mathrm{~m}^{-2}\right)$ was observed in Plot 9a $(N$. olivacea accounted for $98.6 \%$ ). $N$. olivacea in the $\leq 5 \mathrm{~mm}$ class were the most abundant at almost every station (Fig. 2). The largest individual (52.5 mm, 15.2 g) was observed in Plot 8b.

The BMI varied from 4.0 (Stn 7) to 5.0 (Stn 10) between stations and from 4.9 to 5.7 between plots at Stn 10. Significant differences were observed in the BMI, ShMI, and SCI between stations (Fig. 3). The BMI of Nuttallia olivacea was significantly higher at Stns 9 to 11 (river) than at Stns 2, 5, and 7 (lagoon). ShMI was high at Stns 8 and 9, but a clear difference between
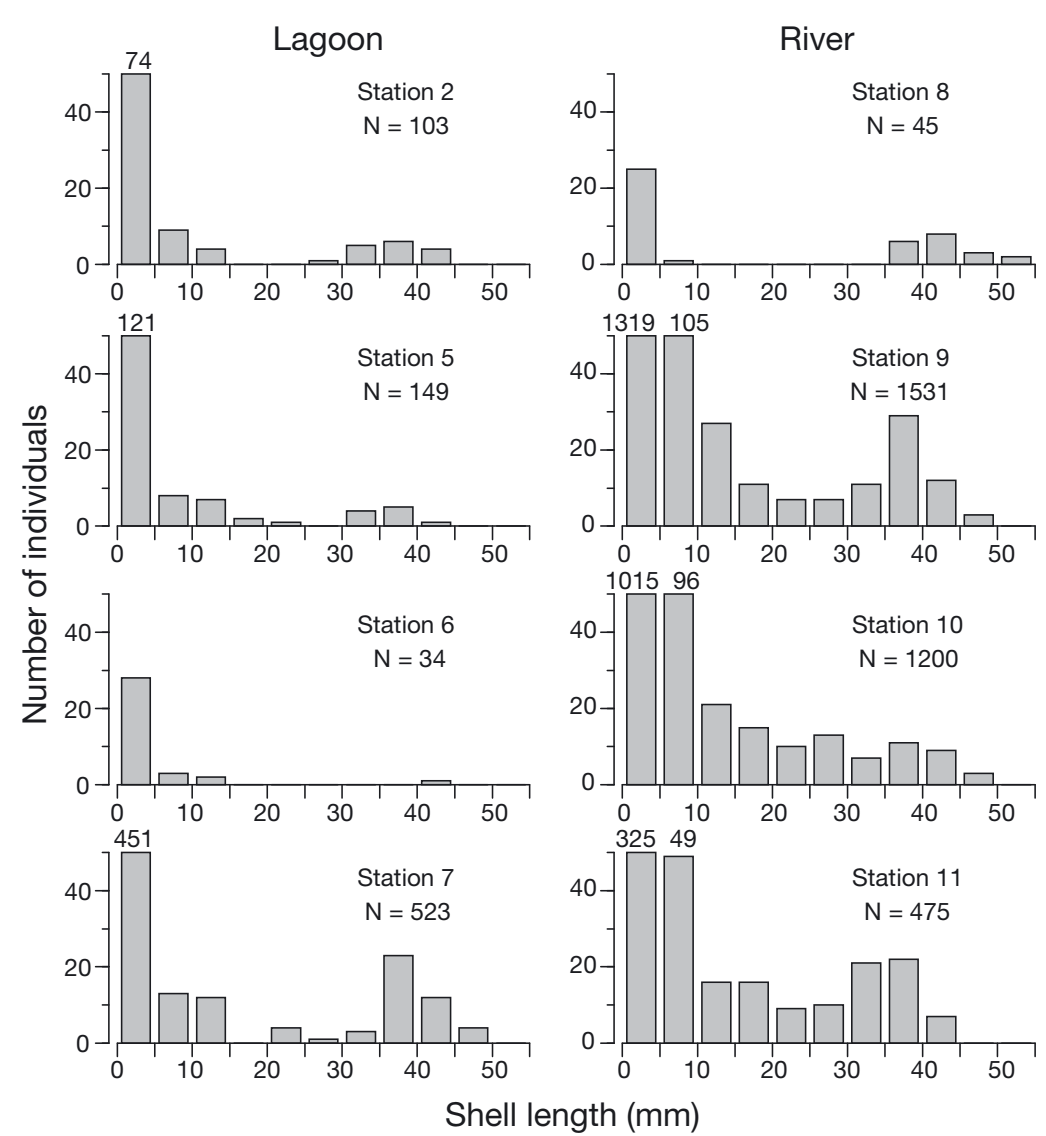

Fig. 2. Nuttallia olivacea. Length-frequency distributions at each station. Data were pooled among plots at each station. Numbers of collected individuals in each size class are shown by numerals above bars when values are $>45$. Stn 4 was excluded because of extremely small sample sizes $(n=4)$ 
lagoon and river was not observed in this parameter. SCI was high at Stns 10 and 11, with a high predation intensity (Table 1).

Variations in BMI, ShMI, and SCI were also observed among plots for some stations (Fig. 4). BMI was high at plots with low elevations at Stns 7, 9, and 11 (Plots 7b, 9c, and 11a). Significant differences in the BMI and SCI were observed at Stn 10, while the greatest difference in ShMI was observed at Stn 9.

\section{Siphon predation by stone flounder}

Juvenile stone flounder Platichthys bicoloratus were abundant at Stns 7, 9, and 11 (Table 1). Total length of juveniles ranged from 16.0 to $64.7 \mathrm{~mm}(\mathrm{n}=277$, mean $\pm \mathrm{SD}=30.3 \pm 9.6 \mathrm{~mm}$ ). Stomach contents of stone flounder consisted chiefly of Nuttallia olivacea siphons ( $35 \%$ in number), palps of polychaetes $(15 \%)$, poly-
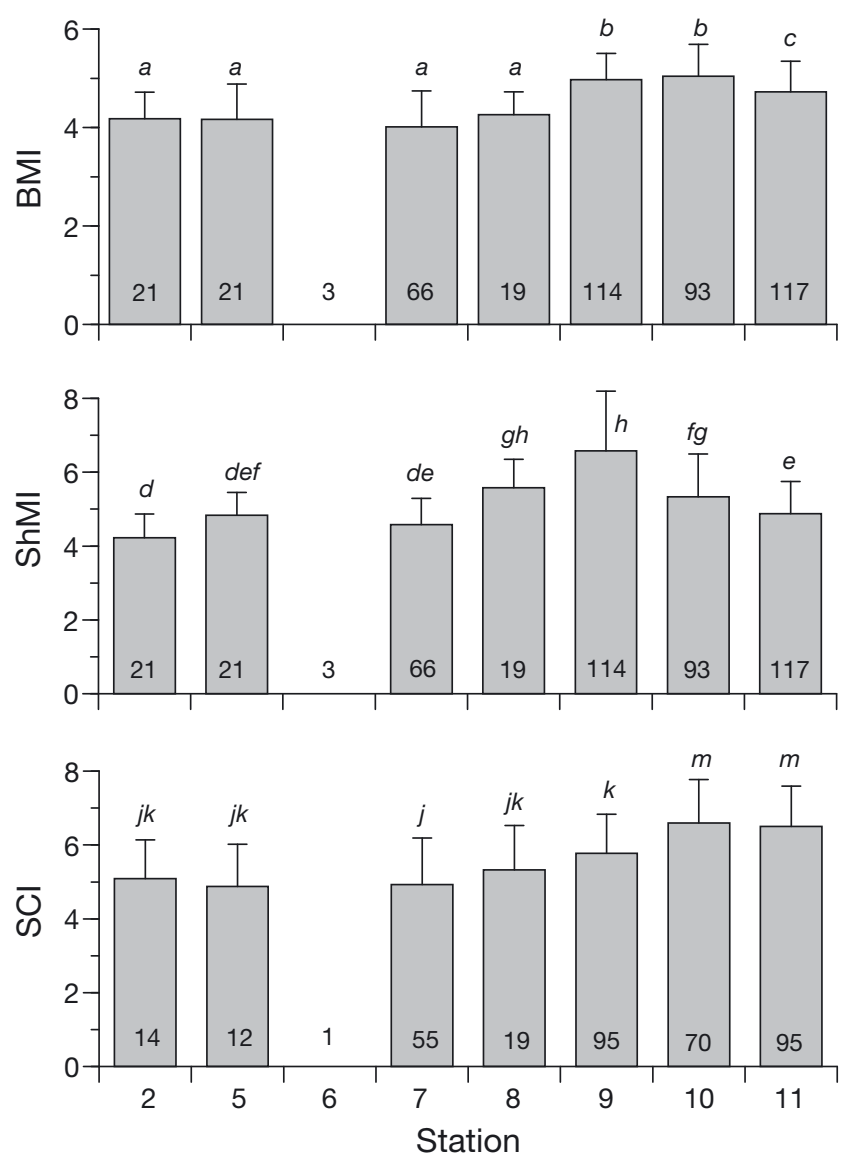

Fig. 3. Nuttallia olivacea. Body mass index (BMI), shell mass index (ShMI), and siphon condition index (SCI) at the sampling stations. Error bars: SD. Numerals in bars: sample sizes. Stn 6 was not considered due to its small sample size $(\mathrm{n}<5)$. Significant differences $(\mathrm{p}<0.05)$ are shown by different letters, tested using the Steel-Dwass test chaetes $(3 \%)$, oligochaetes $(16 \%)$, copepods $(7 \%)$, ostracods $(14 \%)$, and other crustaceans (5\%). Siphons of other bivalves were observed only rarely $(1 \%)$. Relative predation intensity on siphons of $N$. olivacea was estimated to be high at Stns 7, 10, and 11 .

\section{Relationships with abiotic and biotic variables}

An environmental threshold for the presence of Nuttallia olivacea was observed for silt-clay contents $(<30 \%)$ and chl a levels $\left(>0.2 \mu \mathrm{g} \mathrm{g}^{-1}\right)$. Plots with high abundances $\left(>1000\right.$ ind. $\left.\mathrm{m}^{-2}\right)$ were characterized by low silt-clay contents $(<15 \%)$ and high chl a levels $\left(>2.5 \mu \mathrm{g} \mathrm{g}^{-1}\right)$.

Our GLMs explained from 47 to $74 \%$ of the deviances in the variation of the presence/absence and abundance of Nuttallia olivacea (Table 3). Salinity, siltclay content, and chl a level were selected for the presence/absence data: $N$. olivacea tended to be collected at sites with high salinity, low silt-clay contents, and high chl a levels. Silt-clay content was also selected for the abundances of both juvenile and adult $N$. olivacea. $\mathrm{Chl} a$ levels and relative elevation were selected only for the abundance of adults. Relative elevation was the most important variable accounting for variation in the abundance of adults, as adults were abundant at sites with low elevation. The abundances of both juveniles and adults were positively correlated with the total abundance of other bivalves. Juvenile abundance was accounted for by adult abundance, but the reverse was not true. For example, a low abundance of adults with a high abundance of juveniles was observed in Plots 9d and 9e (9d: 226 juveniles and 12 adults; 9e: 330 juveniles and 5 adults).

The GLM explained from 25 to $60 \%$ of deviances in weight parameters (Table 4). Both silt-clay content and relative elevation negatively affected all response variables for Nuttallia olivacea condition. Silt-clay content and the elevation accounted, respectively, for 5.5 and $21.1 \%$ of the deviances for SBW. Chl a level was selected for SBW and ShW, but the correlations were negative. Bivalve abundance (biomass) was also selected and was important for ShW (explained 6.7\% of the deviance). Siphon predation intensity was selected for both SBW and ISW, although it explained only from 1.2 to $1.8 \%$ of the deviances. Its correlations were negative for SBW, but positive for ISW.

\section{Laboratory experiment}

The SBW and ISW of Nuttallia olivacea reared with stone flounder were smaller than those reared with goby or in the control (Fig. 5). The treatment was 
selected as an explanatory factor for both SBW and ISW. Significant reduction in SBW was observed in the aquarium with flounders, while SBW was not significantly affected by the presence of gobies (Table 5). No significant difference was observed in ISW, although the ISW of bivalves in the flounder treatment was smaller than that of bivalves in the control. Treatment explained 7.7 and $4.6 \%$ of the deviances in models for SBW and ISW, respectively.

\section{DISCUSSION}

The present study (1) clearly demonstrated the spatial heterogeneity in the abundance and condition of the bivalve Nuttallia olivacea at 2 spatial scales (stations and plots), (2) determined that silt-clay content and elevation largely affected the spatial variation in abundance and condition, (3) confirmed the negative effect of sublethal siphon predation by stone flounder
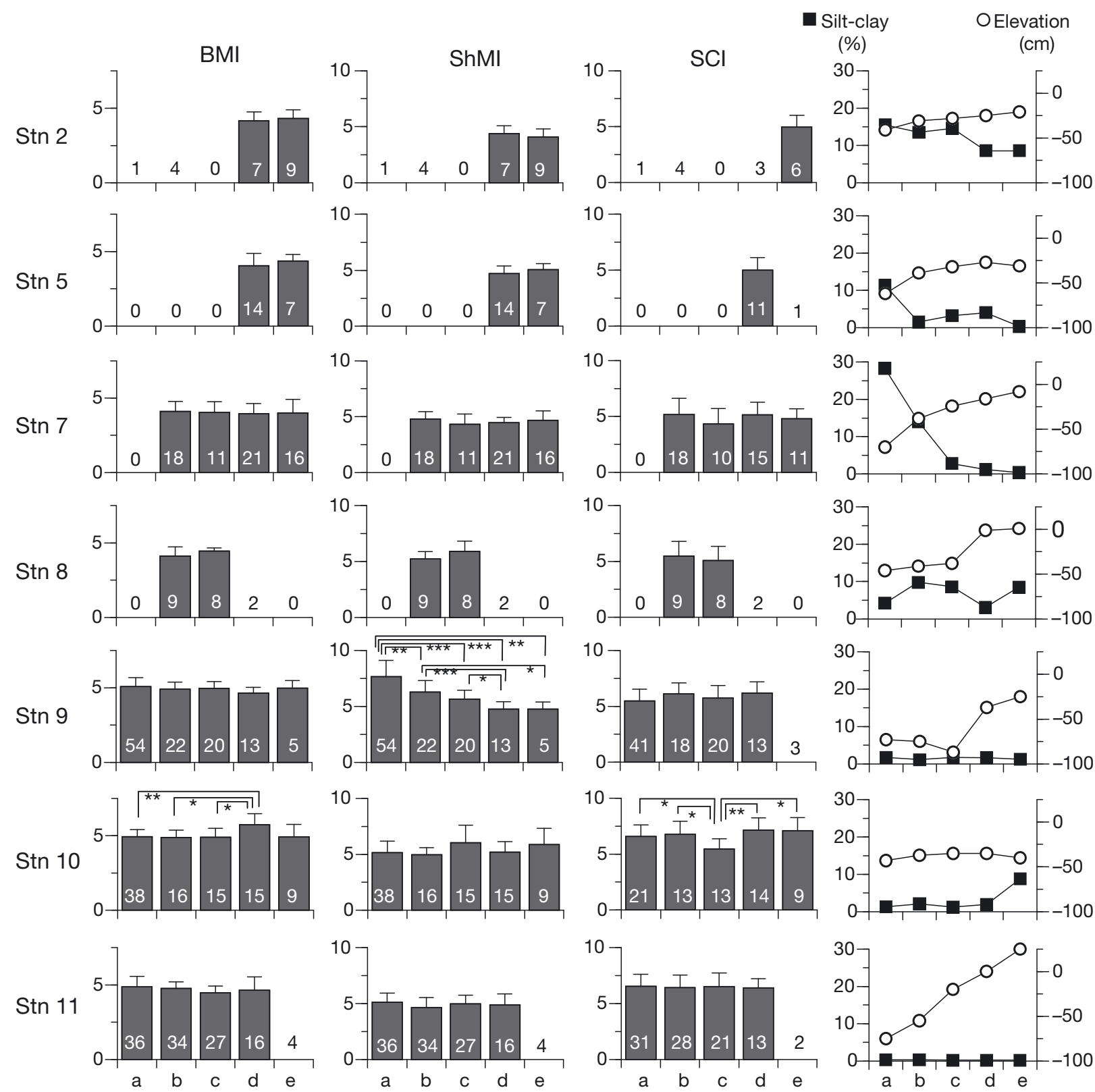

Plot

Fig. 4. Nuttallia olivacea. BMI, ShMI, SCI, and environmental factors ( $\mathbf{\square}$ silt-clay content, $\mathrm{O}$ relative elevation) in the sampling plots at each station. Error bars: SD. Numerals in bars: sample sizes. Plots with small sample sizes $(<5)$ were not considered.

Significant differences are shown by asterisks $\left({ }^{*}: \mathrm{p}<0.05{ }^{* *}: \mathrm{p}<0.01{ }^{* * *}: \mathrm{p}<0.001\right)$, tested using the Steel-Dwass test 
Table 3. Nuttallia olivacea. Analysis of deviance and parameter estimates for generalized linear models (GLM) for the presence/absence and abundance of $N$. olivacea. Explanatory variables in the models selected based on the Akaike information criterion (AIC) are shown. Salinity, silt-clay content, chl a level, and relative elevation were used as initial variables. Abundance of individuals in alternative classes (juvenile or adult) and abundance of other bivalve species were added as initial variables for abundances. A chi-square test was used for analysis of deviance. ED: explained deviance of the model; adult: abundance of adult $N$. olivacea; others: abundance of other bivalve species

\begin{tabular}{|c|c|c|c|c|c|c|c|}
\hline \multicolumn{4}{|c|}{ GLM deviance } & \multirow{2}{*}{ Parameter } & \multicolumn{2}{|c|}{ — GLM summaries } & \multirow[b]{2}{*}{$\mathrm{p}$} \\
\hline Error source & $\mathrm{df}$ & Deviance & $\mathrm{p}$ & & Estimate & $\mathrm{SE}$ & \\
\hline \multicolumn{8}{|c|}{ Presence/absence (family = binomial [logit-link], ED $=47 \%$ ) } \\
\hline Error & 46 & 31.4 & & Intercept & -4.44 & 2.86 & 0.12 \\
\hline Salinity & 1 & 5.9 & 0.015 & Salinity & 0.25 & 0.13 & 0.049 \\
\hline Silt-clay & 1 & 15.8 & $<0.001$ & Silt-clay & -0.18 & 0.06 & 0.001 \\
\hline $\mathrm{Chl} \mathrm{a}$ & 1 & 6.2 & 0.013 & Chl a & 0.51 & 0.24 & 0.035 \\
\hline \multicolumn{8}{|c|}{ Juvenile abundance (family = negative binomial [log-link], ED = 61\%) } \\
\hline Error & 30 & 37.9 & & Intercept & 6.15 & 1.01 & $<0.001$ \\
\hline Salinity & 1 & 1.6 & 0.21 & Salinity & -0.10 & 0.04 & 0.009 \\
\hline Silt-clay & 1 & 37.5 & $<0.001$ & Silt-clay & -0.14 & 0.03 & $<0.001$ \\
\hline Adult & 1 & 3.4 & 0.07 & Adult & 0.05 & 0.02 & 0.019 \\
\hline Others & 1 & 15.8 & $<0.001$ & Others & 0.05 & 0.02 & 0.019 \\
\hline \multicolumn{8}{|c|}{ Adult abundance (family = negative binomial [log-link], ED = $74 \%$ ) } \\
\hline Error & 23 & 33.9 & & Intercept & 0.20 & 0.50 & 0.68 \\
\hline Salinity & 1 & 8.5 & 0.003 & Salinity & 0.06 & 0.02 & $<0.001$ \\
\hline Silt-clay & 1 & 19.3 & $<0.001$ & Silt-clay & -0.05 & 0.02 & 0.003 \\
\hline Chl a & 1 & 16.4 & $<0.001$ & Chl a & 0.08 & 0.03 & 0.004 \\
\hline Elevation & 1 & 36.9 & $<0.001$ & Elevation & -0.01 & 0.003 & $<0.001$ \\
\hline Others & 1 & 16.3 & $<0.001$ & Others & 0.02 & 0.006 & $<0.001$ \\
\hline
\end{tabular}

Table 4. Nuttallia olivacea. Analysis of deviance and parameter estimates for GLMs of body condition. Response variables were SBW, ShW, and ISW, introducing offset terms ( $\ln \left[\mathrm{ShL}^{3}\right]$ for SBW and ShW and $\ln \left[\mathrm{SBW}^{0.83}\right]$ for ISW) in the models, instead of BMI, ShMI, and SCI, respectively (see Table 2 for abbreviations). Explanatory variables of the models, selected based on AIC, are shown. Salinity, silt-clay content, chl a level, relative elevation, individual body size (ShL), and bivalve biomass were used as initial variables. Predation intensity on siphons was added as an initial variable, except for shell weight. A chi-square test was used for analysis of deviance. ED: see Table 3; biomass: total weight of bivalves

\begin{tabular}{|c|c|c|c|c|c|c|c|}
\hline \multirow{2}{*}{ Error source } & \multicolumn{2}{|c|}{ - GLM deviance } & \multirow[b]{2}{*}{$\mathrm{p}$} & \multirow[b]{2}{*}{ Parameter } & \multicolumn{2}{|c|}{ — GLM summaries _ } & \multirow[b]{2}{*}{$\mathrm{p}$} \\
\hline & $\mathrm{df}$ & Deviance & & & Estimate & SE & \\
\hline \multicolumn{8}{|c|}{ SBW $\left(\right.$ family $=$ Gaussian $[$ log-link $]$, offset $=\ln \left[\mathrm{ShL}^{3}\right], \mathrm{ED}=36 \%$ ) } \\
\hline Error & 447 & 32.4 & & Intercept & -9.79 & 0.064 & $<0.001$ \\
\hline Silt-clay & 1 & 2.8 & $<0.001$ & Silt-clay & -0.005 & 0.002 & 0.018 \\
\hline Chl a & 1 & 1.8 & $<0.001$ & Chl a & -0.011 & 0.005 & 0.022 \\
\hline Elevation & 1 & 10.8 & $<0.001$ & Elevation & -0.003 & 0.0004 & $<0.001$ \\
\hline ShL & 1 & 2.4 & $<0.001$ & ShL & -0.008 & 0.001 & $<0.001$ \\
\hline Biomass & 1 & 0.2 & 0.15 & Biomass & 0.0004 & 0.0002 & 0.020 \\
\hline Predation & 1 & 0.6 & 0.004 & Predation & -0.007 & 0.002 & $<0.001$ \\
\hline \multicolumn{8}{|c|}{ ShW $\left(\right.$ family $=$ Gaussian $[$ log-link $]$, offset $=\ln \left[\mathrm{ShL}^{3}\right], \mathrm{ED}=60 \%$ ) } \\
\hline Error & 447 & 83.6 & & Intercept & -9.84 & 0.11 & $<0.001$ \\
\hline Salinity & 1 & 15.8 & $<0.001$ & Salinity & -0.011 & 0.002 & $<0.001$ \\
\hline Silt-clay & 1 & 9.6 & $<0.001$ & Silt-clay & -0.009 & 0.003 & 0.001 \\
\hline Chl a & 1 & 56.5 & $<0.001$ & Chl $a$ & -0.019 & 0.006 & $<0.001$ \\
\hline Elevation & 1 & 24.9 & $<0.001$ & Elevation & -0.001 & 0.001 & 0.011 \\
\hline ShL & 1 & 2.9 & $<0.001$ & ShL & 0.006 & 0.002 & 0.001 \\
\hline Biomass & 1 & 14.0 & $<0.001$ & Biomass & 0.002 & 0.0002 & $<0.001$ \\
\hline \multicolumn{8}{|c|}{ ISW $\left(\right.$ family $=$ Gaussian $[\log -\operatorname{link}]$, offset $=\ln \left[\mathrm{SBW}^{0.83}\right], \mathrm{ED}=25 \%$ ) } \\
\hline Error & 355 & 0.145 & & Intercept & -2.37 & 0.085 & $<0.001$ \\
\hline Silt-clay & 1 & 0.005 & $<0.001$ & Silt-clay & -0.007 & 0.003 & 0.026 \\
\hline Elevation & 1 & $3 \times 10^{-5}$ & 0.78 & Elevation & -0.001 & 0.001 & 0.13 \\
\hline ShL & 1 & 0.036 & $<0.001$ & ShL & -0.013 & 0.002 & $<0.001$ \\
\hline Biomass & 1 & 0.004 & 0.003 & Biomass & -0.0003 & 0.0002 & 0.060 \\
\hline Predation & 1 & 0.003 & 0.004 & Predation & 0.007 & 0.002 & 0.004 \\
\hline
\end{tabular}


Platichthys bicoloratus on the somatic condition of the bivalves from the field survey and the laboratory experiment, and (4) found that the effects of environmental factors override the impact of sublethal predation on conditions of the bivalves.

\section{Bivalve abundance-environment relationships}

Silt-clay content and chl a level thresholds indicate that these factors are constraints for the presence of Nuttallia olivacea. Low salinity may also limit their distribution, because the bivalves were seldom observed at areas with salinities consistently <10 (Tomiyama \& Omori 2008). Silt-clay content was an important explanatory variable for the abundance of juvenile and adult $N$. olivacea. However, deviances in the GLM indicate that low silt-clay content is most important for juvenile abundance, while low elevation is more important for adult abundance (Table 3). This result agrees with the observations of Akiyama (1988) that high density sites had lower silt-clay levels for juveniles than for adults of $N$. olivacea. Chl a level, representing food availability, would be less important for bivalve abundance, but extremely low chl a level possibly results in the low survival or limited growth.

Juvenile abundance was positively correlated with adult abundance (Table 3 ). This result may indicate that recruitment is facilitated around high densities of adults, as has been reported in suspension-feeding clams (Peterson \& Black 1993). This pattern is different from a negative adult-juvenile interaction, whereby a high abundance of adults inhibits larval and juvenile recruitments by ingestion (André \& Rosenberg 1991, Thrush et al. 1997). It should be noted that adult densities do not necessarily affect the
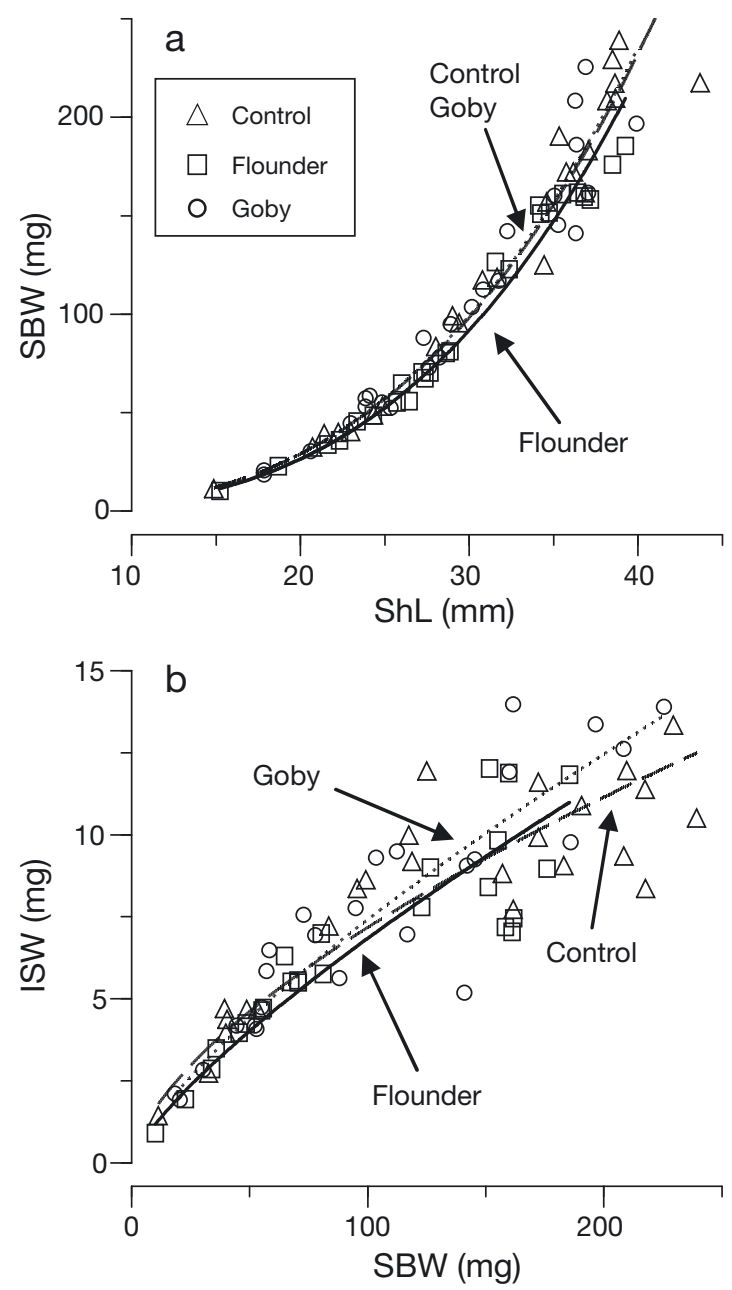

Fig. 5. Nuttallia olivacea. Relationships between (a) shell length (ShL) and soft body weight (SBW) and (b) SBW and inhalant siphon weight (ISW) for each treatment (flounder, goby, and control) in the laboratory experiment. Allometric regressions were applied

Table 5. Nuttallia olivacea. Analysis of deviance and parameter estimates for GLMs for body condition in the laboratory experiment. Response variables were SBW and ISW (abbreviations in Table 2), introducing offset terms into the models. All explanatory variables were selected for both conditions based on AIC. Treatments included flounder, goby, and control. ED: see Table 3

\begin{tabular}{|c|c|c|c|c|c|c|c|}
\hline \multicolumn{4}{|c|}{$\longrightarrow$ GLM deviance $\longrightarrow$} & \multirow[b]{2}{*}{ Parameter } & \multicolumn{2}{|c|}{ GLM summaries } & \multirow[b]{2}{*}{$\mathrm{p}$} \\
\hline Error source & $\mathrm{df}$ & Deviance & $\mathrm{p}$ & & Estimate & SE & \\
\hline \multicolumn{8}{|c|}{ SBW $\left(\right.$ family $=$ Gaussian $[\log$-link $]$, offset $=\ln \left[\mathrm{ShL}^{3}\right], \mathrm{ED}=20 \%$ ) } \\
\hline Error & 71 & 16921 & & Intercept & -5.20 & 0.12 & $<0.001$ \\
\hline \multirow[t]{2}{*}{ Treatment } & 2 & 1627.2 & 0.033 & Flounder & -0.087 & 0.036 & 0.017 \\
\hline & & & & Goby & -0.009 & 0.034 & 0.79 \\
\hline ShL & 1 & 2687.5 & $<0.001$ & ShL & -0.012 & 0.003 & $<0.001$ \\
\hline \multicolumn{8}{|c|}{ ISW $\left(\right.$ family $=$ Gaussian $[\log$-link $]$, offset $\left.=\ln \left[\mathrm{SBW}^{0.71}\right], \mathrm{ED}=15 \%\right)$} \\
\hline Error & 71 & 143.7 & & Intercept & -0.95 & 0.15 & $<0.001$ \\
\hline \multirow[t]{2}{*}{ Treatment } & 2 & 7.9 & 0.14 & Flounder & -0.027 & 0.053 & 0.61 \\
\hline & & & & Goby & 0.073 & 0.049 & 0.14 \\
\hline ShL & 1 & 17.2 & 0.004 & ShL & -0.011 & 0.004 & 0.011 \\
\hline
\end{tabular}


recruitment density (Ólafsson 1989) because uningested bivalve larvae may be able to survive (André et al. 1993).

Juvenile abundance did not explain adult abundance (Table 3), indicating that adults are not necessarily abundant at habitats in which juveniles are abundant. The spatial separation of juveniles and adults can be due to migration and/or mortality. The migration of juveniles to lower areas has been observed in Macoma balthica (Beukema \& de Vlas 1989, Bouma et al. 2001, Hiddink \& Wolff 2002). This change is likely related to habitat suitability, e.g. higher survival of adults at the lower intertidal (Beukema 1993).

Our GLM well explained the presence/absence and abundance of Nuttallia olivacea. However, juvenile recruitment to adult populations may be affected by predation and/or other unconsidered factors. Predation directly controls the benthic community (Jensen \& Jensen 1985, Richards et al. 1999). Emersion time and current velocity may be important for the distribution of bivalves (Kater et al. 2006). Further improvement of the models should promote our understanding of the processes involved in determining distribution patterns.

\section{Bivalve condition-environment relationships}

Spatial variation in the condition of Nuttallia olivacea was revealed not only on a spatial scale of 200 to $800 \mathrm{~m}$ (among stations), but also on a smaller scale of 5 to $20 \mathrm{~m}$ (among plots). Variation in the condition of bivalves among plots is largely attributable to elevation: SBW and ShW were larger at the lower intertidal (Table 4), as observed in Macoma balthica (Beukema 1993, Azouzi et al. 2002). Growth of N. olivacea is also higher in lower intertidal areas (Akiyama 1988). These results are understandable because bivalves at plots with lower elevation can take in more food because of the longer submersion times. The importance of elevation for growth and production is well known (Peterson \& Black 1987, Harvey \& Vincent 1991), although the higher production at the lower intertidal is not common: the highest production of some bivalve species is observed at intermediate intertidal levels (Beukema \& Dekker 2006, Dekker \& Beukema 2007).

Variations in SBW and ShW were partly accounted for by chl a level, with an unexpected negative correlation (Table 4). The reason for the negative correlation was unclear. Food abundance is often positively related to the growth rate of other bivalves (Beukema \& Cadée 1991), but chl a level would be less important than silt-clay content for the growth of Nuttallia oli- vacea (Ito et al. 2005): the bivalves grow rapidly at sites with relatively high chl a levels (2 to $9 \mu \mathrm{g} \mathrm{g}^{-1}$ ) and low silt-clay contents $(<2 \%)$, while the bivalves hardly grow at a site with the highest chl a levels (8 to $12 \mu \mathrm{g}$ $\mathrm{g}^{-1}$ ) and relatively high silt-clay contents (5 to $12 \%$ ). $N$. olivacea is a suspension feeder and therefore sensitive to the contamination of silt-clay in its food. The growth of $N$. olivacea in the laboratory is markedly reduced even under 0.5 to $1 \%$ silt-clay within prey diatoms, compared to when silt-clay levels are between 0 and $0.1 \%$ (Ito et al. 2005). Growth corresponds with the somatic condition, although the somatic condition is more sensitive to environmental changes and responds quickly to factors facilitating growth (Norkko et al. 2005).

Somatic condition was not negatively influenced by bivalve biomass per plot, suggesting a lower importance of density than other environmental factors. Soft body condition was better in denser habitats (Stns 9 to 11; Fig. 3). SBW was positively correlated with bivalve biomass, which mostly consisted of Nuttallia olivacea, indicating that the density effects are less at preferable habitats. The density-dependence in productivity is also weak or site specific in Macoma balthica (Ólafsson 1986, van der Meer et al. 2001).

\section{Impact of sublethal predation}

The present study detected negative impacts of sublethal siphon predation on the SBW of bivalves both in the field and laboratory (Tables $4 \& 5$ ). The results correspond with experimental studies that confirm the predation-induced reduction in the somatic condition of bivalves such as Scrobicularia plana (Hodgson 1982) and Macoma balthica (Kamermans \& Huitema 1994, de Goeij et al. 2001). The negative impacts of sublethal predation on soft body condition may be subtle, because the effects of siphon removal on somatic condition have never been detected in field experiments conducted at Stn 9 (Tomiyama \& Ito 2006, Tomiyama \& Omori 2007).

SCI was high at Stn 11, where siphon predation was the most intense (Fig. 4). This result may imply that the regeneration of inhalant siphons after predation (Tomiyama \& Ito 2006) made the reduction in siphon weights negligible. Instead, the reduction in SBW of the bivalves due to energy expense would occur, especially under limited food conditions (in the laboratory or at unsuitable habitats). Effects of the abiotic environmental variables may override those of predation on siphon sizes, because the siphon condition was smaller at $\operatorname{Stn} 7$, which showed a lower predation intensity than at Stn 11 (Figs. 3 \& 4). Our GLM supported this idea, as shown in the small deviances of 
siphon size explained by predation intensity (Table 4). The mechanism causing the small siphon sizes at low predation intensity was unclear, but siphon sizes strongly relate to the burial depth of bivalves (Zwarts 1986, Zwarts \& Wanink 1989, Zwarts et al. 1994). High siphon condition, namely large siphon sizes relative to SBW, may indicate that sufficient burial depths for avoiding lethal predation by birds or other predators are essential for bivalves. Substratum conditions may limit burial depths and, subsequently, siphon sizes. Further surveys and experiments are expected to reveal the impacts of predation and abiotic factors on siphon sizes.

\section{CONCLUSIONS}

Spatial variation in the abundance and condition of Nuttallia olivacea was observed at both spatial scales (stations and plots). Presence/absence and abundance of this species were both largely accounted for by siltclay content, while the soft body condition was determined primarily by relative elevation. Such environmental variables are far more important than siphon predation intensity as factors regulating the condition of the bivalve, although siphon predation negatively affects somatic condition of the bivalves.

Acknowledgements. We thank Y. Chida and members of the Laboratory of Fisheries Biology and Ecology, Graduate School of Agricultural Science, Tohoku University, for their support in sample collection. We also thank anonymous reviewers for helpful comments on the manuscript.

\section{LITERATURE CITED}

Akiyama A (1988) Benthic animals in an intertidal flat. In: Kurihara Y (ed) Ecology and ecotechnology in estuarinecoastal area. Tokai University Press, Tokyo, p 85-98 (in Japanese)

André C, Rosenberg R (1991) Adult-larval interactions in the suspension-feeding bivalves Cerastoderma edule and Mya arenaria. Mar Ecol Prog Ser 71:227-234

- André C, Jonsson PR, Lindegarth M (1993) Predation on settling bivalve larvae by benthic suspension feeders: the role of hydrodynamics and larval behaviour. Mar Ecol Prog Ser 97:183-192

Azouzi L, Bourget E, Borcard D (2002) Spatial variation in the intertidal bivalve Macoma balthica: biotic variables in relation to density and abiotic factors. Mar Ecol Prog Ser 234:159-170

Beukema JJ (1993) Successive changes in distribution patterns as an adaptive strategy in the bivalve Macoma balthica (L.) in the Wadden Sea. Helgol Meersunters 47: 287-304

Beukema JJ, Cadée GC (1991) Growth rates of the bivalve Macoma balthica in the Wadden Sea during a period of eutrophication: relationships with concentrations of pelagic diatoms and flagellates. Mar Ecol Prog Ser 68:249-256
Beukema JJ, Dekker R (2006) Annual cockle Cerastoderma edule production in the Wadden Sea usually fails to sustain both wintering birds and a commercial fishery. Mar Ecol Prog Ser 309:189-204

Beukema JJ, de Vlas J (1989) Tidal-current transport of thread-drifting postlarval juveniles of the bivalve Macoma balthica from the Wadden Sea to the North Sea. Mar Ecol Prog Ser 52:193-200

Bonsdorff E, Norkko A, Sandberg E (1995) Structuring zoobenthos: the importance of predation, siphon cropping and physical disturbance. J Exp Mar Biol Ecol 192: 125-144

Bouma H, de Vries PP, Duiker JMC, Herman PMJ, Wolff WJ (2001) Migration of the bivalve Macoma balthica on a highly dynamic tidal flat in the Westerschelde estuary, The Netherlands. Mar Ecol Prog Ser 224:157-170

Cardoso JFMF, Witte JIJ, van der Veer HW (2007) Habitat related growth and reproductive investment in estuarine waters, illustrated for the tellinid bivalve Macoma balthica (L.) in the western Dutch Wadden Sea. Mar Biol 152: 1271-1282

> Coen LD, Heck KL Jr (1991) The interacting effects of siphon nipping and habitat on bivalve (Mercenaria mercenaria (L.)) growth in a subtropical seagrass (Halodule wrightii Aschers) meadow. J Exp Mar Biol Ecol 145:1-13

Crawly MJ (2005) Statistics: an introduction using R. Wiley, London

de Goeij P, Luttikhuizen P (1998) Deep-burying reduces growth in intertidal bivalves: field and mesocosm experiments with Macoma balthica. J Exp Mar Biol Ecol 228: 327-337

> de Goeij P, Luttikhuizen PC, van der Meer J, Piersma T (2001) Facilitation on an intertidal mudflat: the effect of siphon nipping by flatfish on burying depth of the bivalve Macoma balthica. Oecologia 126:500-506

> Dekker R, Beukema JJ (2007) Long-term and large-scale variability in productivity of the tellinid bivalve Macoma balthica on Wadden Sea tidal flats. Mar Ecol Prog Ser 337: $117-134$

> de Vlas J (1979) Annual food intake by plaice and flounder in a tidal flat area in the Dutch Wadden Sea, with special reference to consumption of regenerating parts of macrobenthic prey. Neth J Sea Res 13:117-153

de Vlas J (1985) Secondary production by siphon regeneration in a tidal flat population of Macoma balthica. Neth J Sea Res 19:147-164

Edelaar P, Piersma T, Postma E (2005) Retained non-adaptive plasticity: gene flow or small inherent costs of plasticity? Evol Ecol Res 7:489-495

Galimberti ME (1996) Biological production process of Nuttallia olivacea (Jay, 1857) in estuary. MS thesis, Tohoku University, Sendai

Harvey M, Vincent B (1991) Spatial variability of lengthspecific production in shell, somatic tissue and sexual products of Macoma balthica in the Lower St. Lawrence Estuary. I. Small and meso scale variability. Mar Ecol Prog Ser 75:55-66

Hattori T, Okuda T, Narimatsu Y, Ueda Y, Ito M (2009) Spatiotemporal variations in nutritional status and feeding habits of immature female bighand thornyhead Sebastolobus macrochir off the Pacific coast of northern Honshu, Japan. Fish Sci 75:611-618

> Hiddink JG, Wolff WJ (2002) Changes in distribution and decrease in numbers during migration of the bivalve Macoma balthica. Mar Ecol Prog Ser 233:117-130

$>$ Hodgson AN (1982) Studies on wound healing, and an estimation of the rate of regeneration, of the siphon of Scro- 
bicularia plana (da Costa). J Exp Mar Biol Ecol 62: $117-128$

Honkoop PJC, Beukema JJ (1997) Loss of body mass in winter in three intertidal bivalve species: an experimental and observational study of the interacting effects between water temperature, feeding time and feeding behaviour. J Exp Mar Biol Ecol 212:277-297

Irlandi EA, Mehlich ME (1996) The effect of tissue cropping and disturbance by browsing fishes on growth of two species of suspension-feeding bivalves. J Exp Mar Biol Ecol 197:279-293

Ito K, Kaga T, Sasaki K, Omori M (2005) Biological production process and food environment for bivalves in tidal flat. Bull Fish Res Agency (Suppl 3):1-15 (in Japanese with English abstract)

> Jensen KT, Jensen JN (1985) The importance of some epibenthic predators on the density of juvenile benthic macrofauna in the Danish Wadden Sea. J Exp Mar Biol Ecol 89: $157-174$

Kamermans P, Huitema HJ (1994) Shrimp (Crangon crangon L.) browsing upon siphon tips inhibits feeding and growth in the bivalve Macoma balthica (L.). J Exp Mar Biol Ecol 175:59-75

Kanaya G, Kikuchi E (2008) Spatial changes in a macrozoobenthic community along environmental gradients in a shallow brackish lagoon facing Sendai Bay, Japan. Estuar Coast Shelf Sci 78:674-684

Kater BJ, Geurts van Kessel AJM, Baars JJMD (2006) Distribution of cockles Cerastoderma edule in the eastern Scheldt: habitat mapping with abiotic variables. Mar Ecol Prog Ser 318:221-227

> Morrisey DJ, Howitt L, Underwood AJ, Stark JS (1992) Spatial variation in soft-sediment benthos. Mar Ecol Prog Ser 81: 197-204

Nanami A, Saito H, Akita T, Motomatsu K, Kuwahara H (2005) Spatial distribution and assemblage structure of macrobenthic invertebrates in a brackish lake in relation to environmental variables. Estuar Coast Shelf Sci 63: $167-175$

Norkko J, Pilditch CA, Thrush SF, Wells RMG (2005) Effects of food availability and hypoxia on bivalves: the value of using multiple parameters to measure bivalve condition in environmental studies. Mar Ecol Prog Ser 298:205-218

Ólafsson EB (1986) Density dependence in suspension-feeding and deposit-feeding populations of the bivalve Macoma balthica: a field experiment. J Anim Ecol 55: 517-526

Ólafsson EB (1989) Contrasting influences of suspensionfeeding and deposit-feeding populations of Macoma balthica on infaunal recruitment. Mar Ecol Prog Ser 55: 171-179

Peterson CH, Black R (1987) Resource depletion by active suspension feeders on tidal flats: influence of local density and tidal elevation. Limnol Oceanogr 32:143-166

> Peterson CH, Black R (1993) Experimental tests of the advantages and disadvantages of high density for two coexisting cockles in a Southern Ocean lagoon. J Anim Ecol 62: 614-633

Peterson CH, Quammen ML (1982) Siphon nipping: its importance to small fishes and its impact on growth of the bivalve Protothaca staminea (Conrad). J Exp Mar Biol Ecol 63:249-268

Richards MG, Huxham M, Bryant A (1999) Predation: a causal mechanism for variability in intertidal bivalve populations. J Exp Mar Biol Ecol 241:159-177

Editorial responsibility: Hans Heinrich Janssen, Oldendorf/Luhe, Germany
Salas C, Tirado C, Manjón-Cabeza ME (2001) Sublethal footpredation on Donacidae (Mollusca: Bivalvea). J Sea Res 46:43-56

Sasaki K, Kudo M, Tomiyama T, Ito K, Omori M (2002) Predation pressure on the siphons of the bivalve Nuttallia olivacea by the juvenile stone flounder Platichthys bicoloratus in the Natori River estuary, north-eastern Japan. Fish Sci 68:104-116

Tallqvist M, Sandberg-Kilpi E, Bonsdorff E (1999) Juvenile flounder, Platichthys flesus (L.), under hypoxia: effects on tolerance, ventilation rate and predation frequency. J Exp Mar Biol Ecol 242:75-93

> Thrush SF, Cummings VJ, Dayton PK, Ford R and others (1997) Matching the outcome of small-scale density manipulation experiments with larger scale patterns an example of bivalve adult/juvenile interactions. J Exp Mar Biol Ecol 216:153-169

> Thrush SF, Hewitt JE, Herman PMJ, Ysebaert T (2005) Multiscale analysis of species-environment relationships. Mar Ecol Prog Ser 302:13-26

Tomiyama T, Ito K (2006) Regeneration of lost siphon tissues in the tellinacean bivalve Nuttallia olivacea. J Exp Mar Biol Ecol 335:104-113

Tomiyama T, Omori M (2007) Interactive effects of sublethal predation and body size on siphon production of the bivalve Nuttallia olivacea. J Exp Mar Biol Ecol 341: 102-109

Tomiyama T, Omori M (2008) Habitat selection of stone and starry flounders in an estuary in relation to feeding and survival. Estuar Coast Shelf Sci 79:475-482

- Tomiyama T, Sasaki K, Omori M (2004) Predator-prey size relationship in siphon cropping between the juvenile stone flounder Platichthys bicoloratus and the bivalve Nuttallia olivacea. Fish Sci 70:531-536

Tomiyama T, Katayama S, Omori M, Honda H (2005) Importance of feeding on regenerable parts of prey for juvenile stone flounder Platichthys bicoloratus in estuarine habitats. J Sea Res 53:297-308

> Tomiyama T, Omori M, Minami T (2007) Feeding and growth of juvenile stone flounder in estuaries: generality and the importance of sublethal tissue cropping of benthic invertebrates. Mar Biol 151:365-376

> Tomiyama T, Komizunai N, Shirase T, Ito K, Omori M (2008) Spatial intertidal distribution of bivalves and polychaetes in relation to environmental conditions in the Natori River estuary, Japan. Estuar Coast Shelf Sci 80:243-250

van der Meer J, Beukema JJ, Dekker R (2001) Long-term variability in secondary production of an intertidal bivalve population is primarily a matter of recruitment variability. J Anim Ecol 70:159-169

Ysebaert T, Herman PMJ (2002) Spatial and temporal variation in benthic macrofauna and relationships with environmental variables in an estuarine, intertidal softsediment environment. Mar Ecol Prog Ser 244:105-124

Zwarts L (1986) Burying depth of the benthic bivalve Scrobicularia plana (da Costa) in relation to siphon-cropping. J Exp Mar Biol Ecol 101:25-39

Zwarts L, Wanink J (1989) Siphon size and burying depth in deposit- and suspension-feeding benthic bivalves. Mar Biol 100:227-240

> Zwarts L, Blomert AM, Spaak P, de Vries B (1994) Feeding radius, burying depth and siphon size of Macoma balthica and Scrobicularia plana. J Exp Mar Biol Ecol 183: 193-212

Submitted: September 24, 2009; Accepted: February 3, 2010 Proofs received from author(s): May 1, 2010 